\title{
Prospects and development of electricity supply in the city of Tashkent
}

\author{
A G Saidxodjayev ${ }^{1}, V K$ Vanin $^{2}$, Alibekova $T S^{3}, U M$ Turdiyev $^{1}, N A$ Toshpulatov ${ }^{1}$ \\ ${ }^{1}$ Tashkent state technical university named after Islam Karimov, Tashkent, Uzbekistan \\ ${ }^{2}$ Peter the Great St. Petersburg Polytechnic University \\ ${ }^{3}$ Karakalpak State University
}

\begin{abstract}
The problems of Electricity Supply of Tashkent for further perspectives are being under consideration. The most exact scheme of electricity supply is taken. The Electricity Supply of the city in recommended.
\end{abstract}

\section{Introduction}

At the first stage of its development, urban networks were built only for outdoor lighting of the city, and later on, residential and public buildings began to consume electricity in cities. To meet the needs of the city, power stations were built inside the city. For example, in Tashkent, such stations as Diesel, Boz-Su HPP, Tash CHPP, etc. In the future, power plants appear outside the city near fuel and water resources. These stations were interconnected by power lines, and as the power system developed and electricity was introduced into everyday life and industry, the electric networks of cities began to connect to large regional substations of the power system [1-4].

In big cities, power supply systems are being created, which are understood as lines and substations not only 6-10 $\mathrm{kV}$, but also $35-220 \mathrm{kV}$. Due to the high responsibility of urban consumers, redundancy and automation of urban networks are used. Classification of urban networks is possible by purpose (municipal, industrial, electrified transport, etc.). We will divide the networks into distribution and nutritional ones.

Consider in Fig. 1 the following elements of the structure of the city's power supply.

1 - power supply network 35 - $220 \mathrm{kV}$ (HV network);

2 - step-down substations (IP or CPU of a given area);

3 - 6-10 kV power supply network (MV network);

4 - lines of the distribution network 6-10 kV (MV network);

5 - lines of the distribution network $0.38 \mathrm{kV}(\mathrm{LV})$;

6 - inputs to buildings;

7 - TP - transformer station;

8 - RP - distribution point.
The division into networks $\mathrm{VN}, \mathrm{MV}, \mathrm{LV}$ is conditional, since in official documents (PUE, PTB, PTE), there is a division only into LV (below $1000 \mathrm{~V}$ ) and HV (above 1000 V).

In addition to the common divisions of electrical networks, networks are divided into internal (inside buildings) and external. Also distinguish between air and cable networks [5-8].

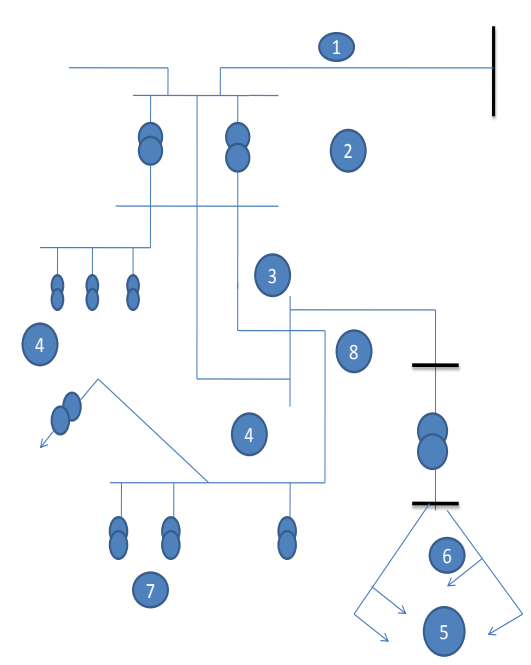

Fig. 1. Following elements of the structure of the city's power supply.

Currently, the power supply of the city of Tashkent is carried out at all standard voltage levels of $0.38 ; 6 ; 10 ; 35$; $110 ; 220 ; 500 \mathrm{kV}$. The supply network includes a $220 \mathrm{kV}$ ring line, two lines along the ring at a voltage of $110 \mathrm{kV}$, and a double-circuit $110 \mathrm{kV}$ line across the city. They connect the main substations of the city, such as Kuylyuk, Ozodlik, etc. These substations have electrical installations at voltages of 
$6,10,35,110,220 \mathrm{kV}$, and the TashGRES substation is additionally $500 \mathrm{kV}$. From these reference substations, district substations are powered and then air and cable lines to power distribution points (RP), transformer points (TP) in all microdistricts. In total, there are more than 5000 transformer stations (TP) in the city at a voltage of 6-10/ $0.38 \mathrm{kV}$. The use of lines and substations at voltages of 6,35 , $220 \mathrm{kV}$ leads to additional losses of power and electricity. Therefore, it is proposed in the future in the power supply scheme of the city of Tashkent, which is close to the "ideal power supply system", to leave two voltage levels of $500 / 110 / 10 \mathrm{kV}$, with the gradual replacement of substations and lines $6 \mathrm{kV}$ by $10 \mathrm{kV}, 35 \mathrm{kV}$ by $110 \mathrm{kV}, 220 \mathrm{kV}$ for 500 $\mathrm{kV}$. As a result, technical power losses, power losses and voltage losses sharply decrease, the transmission capacity of lines and transformers increases [9-12].

In the coming years, it is necessary to revise the entire power supply system of the city at all voltage levels in order to improve the quality of electricity, the requirements for reliability, efficiency and safety of urban electrical networks [13-17].

On the basis of foreign investments, until 2022, it is planned to widely introduce and install new multifunctional electronic "smart meters" based on new computer technology using the Automated Commercial Energy Metering System (ASKUE), which will reduce technical and commercial losses of electricity and reduce the imbalance in the energy system.

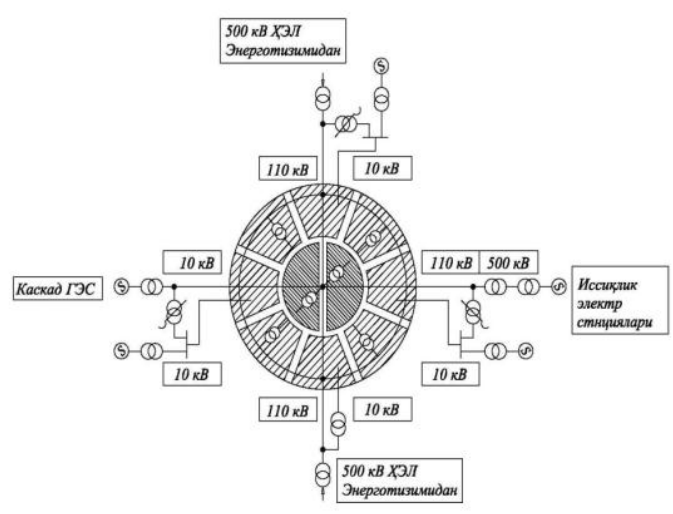

Fig. 2. Perspective scheme of power supply of the city of Tashkent

Figure 2 shows a perspective power supply scheme for the city of Tashkent [one]. Thus, the prospects and development of the power supply of the city of Tashkent should consist of the following stages:

- reducing the number of voltage steps in the city's power supply systems will reduce power and electricity losses;

- the use of an automated energy metering and control system (ASKUE) reduces technical and commercial losses in urban electrical networks;

- development and application of closed electrical networks in urban networks of $0,38-6-10 \mathrm{kV}$ with digital automation elements, using reverse power automatic devices will improve the quality of electrical energy, voltage and load conditions, and reduce technological losses to $4-5 \%$.

With the transition to a market economy, the requirements of electricity consumers and subscribers to the continuity, reliability and quality of electricity have increased dramatically, and this requires new approaches, new methods and ways of rational use of electricity in urban electrical networks [18-21].

The step-by-step solution of these problems is very urgent and necessary for improving the power supply of the city of Tashkent.

\section{References}

1. I.Rakhmonov, A.Berdishev, N.Niyozov, A.Muratov and U.Khaliknazarov. Development of a scheme for generating the predicted value of specific electricity consumption // CONMECHYDRO - 2020. IOP Conf. Series: Materials Science and Engineering. $883 \quad$ (2020) 012103. doi:10.1088/1757-899X/883/1/012103

2. F.A.Hoshimov, I.I.Bakhadirov, M.S.Kurbanbayeva, N.A.Aytbayev. Development of specific standards of energy consumption by types of produced products of the spinning product // RSES 2020. E3S Web of Conferences. 216 (2020) 01169. https://doi.org/10.1051/e3sconf/202021601169

3. F.A.Hoshimov, I.I.Bakhadirov, A.A.Alimov, M.T.Erejepov. Forecasting the electric consumption of objects using artificial neural networks // E3S Web of Conferences. $216 \quad$ (2020) https://doi.org/10.1051/e3sconf/202021601170 01170. 4. I.U.Rakhmonov, F.A.Hoshimov. Development of an algorithm for evaluating the dominant factors that have the greatest impact on the energy intensity of products // ENERGY-21. E3S Web of Conferences. 209 (2020) 07018. https://doi.org/10.1051/e3sconf/202020907018

5. Usmanov E.G. Stability in a parallel resonant circuit with active load // RSES 2020. E3S Web of Conferences. 216 (2020) 01160. https://doi.org/10.1051/e3sconf/202021601160 6. Usmanov E.G., Khusanov B.M. Phase relations in resonant circuits with a wide falling section on the amplitude characteristic // RSES 2020. E3S Web of Conferences. 216 (2020) 01161. https://doi.org/10.1051/e3sconf/202021601161 7. I.U.Rakhmonov, K.M.Reymov. Statistical models of renewable energy intermittency // RSES 2020. E3S Web of Conferences. $\quad 216 \quad 01167$. https://doi.org/10.1051/e3sconf/202021601167

8. I.U.Rakhmonov, N.N.Kurbonov. Analysis of automated software for monitoring energy consumption and efficiency of industrial enterprises // E3S Web of Conferences. 216 (2020) 01178. https://doi.org/10.1051/e3sconf/202021601178

9. F.A.Hoshimov, I.U.Rakhmonov, N.N.Niyozov. Technology to reduce energy costs in the electric steel melting shop // ENERGY-21. E3S Web of Conferences. 209 (2020) 07017. https://doi.org/10.1051/e3sconf/202020907017

10. A.Taslimov, F.Rakhimov, L.Nematov, N.Markaev, A.Bijanov, R.Yunusov. Economic load intervals for selecting $10 \mathrm{kV}$ cable cross-sections for agricultural consumers // CONMECHYDRO - 2020. IOP Conf. Series: Materials Science and Engineering. $883 \quad$ (2020) 012102. doi:10.1088/1757-899X/883/1/012102

11. A.Taslimov, M.Melikuziev, O.Matchonov, M.Ruzinazarov and M.Nasirov. Development of standard cable cross-sections of rural electrical networks // CONMECHYDRO - 2020. IOP Conf. Series: Materials Science and Engineering. $883 \quad$ (2020) 012105. doi:10.1088/1757-899X/883/1/012105 
12. I.Bakhadirov, N.Markaev, G.Aslanova, R.Tanatarov, S.Makhmuthonov. Differentiated tariffs of electricity for the improvement of steelmaking Uzbekistan // CONMECHYDRO - 2020. IOP Conf. Series: Materials Science and Engineering. $883 \quad$ (2020) 012121. doi:10.1088/1757-899X/883/1/012121

13. A.D.Taslimov, A.S.Berdishev, F.M.Rakhimov and A.A.Yuldashev. Optimal tendency of selecting cable crosssections for agricultural electrical networks // ICMSIT-2020. Journal of Physics: Conference Series. 1515 (2020) 022056. doi:10.1088/1742-6596/1515/2/022056

14. Abduraxim Berdishev, Abdurakhim Taslimov, Bakhtiyor Melikuziev and Alibi Bijanov. Reliability indicators of $10 \mathrm{kV}$ cable lines in rural areas // FORM-2020. IOP Conf. Series: Materials Science and Engineering. 869 (2020) 011001. doi:10.1088/1757-899X/869/1/011001

15. A.D.Taslimov. Selection of a complex of parameters of distribution electric networks with respect to technical limitations // ENERGY-21. E3S Web of Conferences. 209 (2020) 07013. https://doi.org/10.1051/e3sconf/202020907013

16. A.D.Taslimov, F.M.Rakhimov, A.O.Norkulov, A.A.Yuldashev. Research of the optimum scale of standard sections of agricultural purpose lines // E3S Web of Conferences. $\quad 216 \quad 01158$. https://doi.org/10.1051/e3sconf/202021601158

17. A.D.Taslimov., M.V.Melikuziev, A.M.Najimova, A.A.Alimov. Economic load intervals for selection of cable sections for agricultural purpose // E3S Web of Conferences. 216 (2020) 01159. https://doi.org/10.1051/e3sconf/202021601159

18. Olimjon Toirov, Tulyagan Kamalov, Utkir Mirkhonov, Sardor Urokov, Dilnoza Jumaeva The mathematical model and a block diagram of a synchronous motor compressor unit with a system of automatic control of the excitation, E3S Web of Conferences, SUSE-2021 (2021)

19. Baratov B., Toshov J., Baynazov U. Method of calculating the gear ratios of the cones of tricone drill bits // E3S Web Conf., Volume 201, 01012, 2020, Ukrainian School of Mining Engineering - 2020. https://doi.org/10.1051/e3sconf/202020101012

20. Haqberdiev A., Toshov J. Analysis of the control system of electric motors of the running gear of self-propelled mine cars used in complex mining and technological conditions // E3S Web of Conferences 216, 01135 (2020), Rudenko International Conference "Methodological problems in reliability study of large energy systems" (RSES 2020), https://doi.org/10.1051/e3sconf/202021601135

21. Karimov R.Ch., Bobojanov M.K., Rasulov A.N., Usmanov E.G. Controlled switching circuits based on nonlinear resistive elements (E3S Web of Conferences, 139, 01039, 2019), https://doi.org/10.1051/e3sconf/201913901039 